\title{
CASE STUDY: READINGS OF CARL PHILIPP EMANUEL BACH'S WÜRTTEMBERG SONATA NO. 3
}

\author{
UDC 781.1/.24.082.2 K. F. E. Bah
}

\section{Bojana Šumanski}

University of Niš, Faculty of Arts, Republic of Serbia

\begin{abstract}
This paper will attempt to question the reliability of such primary elements of a note, which seem fixated-it's pitch and duration. By analyzing the composer's musical language and his way of utilising the notation system we will attempt to bring to light the layer of the text that remains unwritten in the score. We will also try to clarify the extent to which the decisions of a performer are spontaneous or arbitrary.
\end{abstract}

Key words: historically informed performance, music notation, rhythm, ornamentation, Empfindsamkeit stil

\section{INTRODUCTION}

Traditional musical notation remains the dominant way of writing a musical composition over a period of more than three hundred years. In its early form, the aim of any written music was to save it from going into oblivion, or to preserve a tradition (Popović-Mlađenović 1998, 32). Thus, the performance of a piece became distinct from improvisation and, over time, reflected the sort of the planned activity of the composer which was beginning to become focused on paper with more precision (ibid, 34). Despite many attempts within the Western musical culture, especially during the second half of the twentieth century, to create a somewhat more perfect notation system, the traditional one remains inviolable. It has managed to adapt itself, in varying degrees of success, to composers' new demands and different styles over the centuries.

Shortages of the notation system are nevertheless evident no matter how detailed the instructions within the musical text are. Any fixed representation of a composer's idea is insufficient for its complete realisation in sound. Reading the musical text, the performer undoubtedly receives a multitude of information all of which fail to fill the "empty" (ibid, 81 ), the unwritten space on paper that is to be rendered by an interpretation. This apparent

Received May, 2018 / Accepted September 2018

Corresponding author: Bojana Šumanski

University of Niš, Faculty of Arts, Serbia

E-mail: bojana@bojanadimkovic.com 
void can be related to many decisions a performer needs to make regarding dynamics, agogics, pedal, character and atmosphere, tempo, articulation or any other element inherent in the music being prepared; as such it could also represent an ideal opportunity for artistic liberties and creativity. This viewpoint seems especially applicable to the repertoire of earlier musical styles the scores of which do not appear to contain many nuances which connect the musical elements into a clear performance plan and idea of the piece (ibid, 75). As musial styles changed, composers have used the notation system to adapt it to their own ideas, thus making it more complex. There is no surprise that scores of the nineteenth century were becoming increasingly more detailed compared to those of the Baroque and Classical eras. It brings us to the conclusion that composers were less tolerant to performance decisions brought about by different performers' whims. Even with more detailed instructions the relationship between a composer's idea and its text remains unadjusted which leaves it to the interpretator to bring the unwritten layer to life (ibid, 75).

Contrary to this undefined void within the musical text there are elements that should be considered invariable and unambigous. Traditional notation, as a collection of abstract signs and symbols, numbers and words, offers mainly the primary elements of a note: its pitch and duration. The performer knows what to play or sing as well as the way of executing it (if such information exists in the score). The latter quality is also sometimes called the secondary element of a note (ibid, 87).

This paper will attempt to question the reliability of such primary elements of a note which seem fixed - its pitch and duration. By analyzing the composer's musical language and his way of utilising the notation system it will attempt to bring to light the layer of the text that remains unwritten in the score. It is also meant to try and clarify the extent to which the decisions of a performer are spontaneous or arbitrary.

\section{DISCUSSION}

Carl Philipp Emanuel Bach was famously described as the father of classical composers, a statement attributed to Mozart himself who, with these words, considered one of J. S. Bach's sons as one of the important predecessors of the Classical style (Mozart 2015, xxv). C. P. E. Bach was creating during the mid-eighteenth century, those confusing years that were to witness many musical styles brought about by the gap that was created between the Baroque period and Viennese classicism. His music most likely belongs to the Empfindsamer stil, in which the carriers of a musical idea were primarily feeling and affect with their quick successions having the aim to surprise and move the listener above all (Bach 1949, 16). With that in mind, the score of the Württemberg Sonata No. 3 appears strangely destitute of emotion compared to twenty-first century standards, the lack of nuances more likely to resemble the score written by Carl's father than a style known for its expressiveness.

All movements bear a tempo marking (Allegro, Adagio, Vivace), information about the metre, the pitch and the length of each note as well as an occasional articulation marking (mostly ligatures that connect two notes or chords). Frequently present are the dynamic markings forte and piano which are always following each other in quick, beatlike, sucession and oddly relate to not more than one or two bars. However, the dynamic markings for the majority of the music are absent. Of the many ornamentation symbols used throughout the period, three are noted in the piece as well as appoggiaturas that were slowly starting to be written in by composers as a smaller note in front of the main one. 
With so many clues missing from the score, the performer might have the impression that this music welcomes artistic liberties. However, Carl Philipp was an experienced and revered cembalist, fortepianist and pedagogue who wrote, during his lifetime, a treatise which describes the performance practice of the time and that is of great value today. These instructions number some four hundred pages in modern print and had initially appeared in two parts, in 1753 and 1762 respectively, under the title „Versuch über die wahre Art das Clavier zu spielen“. In it there are numerous, detailed instructions regarding fingering, the application of ornaments, figured bass, ensemble playing and improvisation as well as general advice on successful public performance.

\subsection{Ornamentation and its influence on primary elements of the note}

Judging by the sheer volume of the treatise, with detailed explanations and various contexts of musical examples, the chapter on ornaments gives an idea of the importance and actuality the issue carried in the eighteenth century as well as Carl Philipp's desire to be pain-stakingly precise about his ornaments' classification. It cannot be overemphasized that Carl Philipp's rules on ornamentation were not universal in his time by any means. Many composers carried on the previous practice by using one and the same symbol for different kinds of ornaments while others (namely Quantz), had had their own specific set of rules and symbols with some other meaning. In any case, one could say with some degree of certainty that ornaments in C. P. E. Bach's works, should be executed according to the treatise' recommendations, at least on historical keyboard instruments. Following this train of thought it can be concluded that: a) these recommendations were obviously often disregarded by performers who were inserting notes of their own choice, thus following the practice of Italian style ornate decoration, b) Carl Philipp did not want to leave ornamentation to chance, and c) the composer wished for more precision from the performer when reading the text.

Faced with the task of determining the pitch values of an ornament as well as notes' individual duration, the result of the performer's reading had a very different sound realisation when he/she did not take into account the composer's explanations. In case he did, he would know not to take all ornament symbols at face value as many of Carl Philipp's rules alter at least two elements of the main note: its duration and its quality (which answers how it should be performed). The first bar of the first movement in Württemberg Sonata has an appoggiatura $b$ on the third beat, written in small type before its main note $a$ (Figure 1). Carl Philipp was one of the rare composers who advocated that appoggiaturas should be written in their real-time duration (in contrast to customary practice of the eigtheenth century whereby the appoggiatura was usually a quaver or a semiquaver) (ibid, 87) and for its duration to be no less then half of the main note's value, or even two thirds in triple metre (ibid, 90) (Figure 2). However, if the main note is tied to a following note of the same pitch, the main note is prolonged and the duration of the small appoggiatura sign extends with it (ibid, 90). ${ }^{2}$ In practice, this would now look like Figure 3.

\footnotetext{
${ }^{2}$ See examples in figure 74, p. 90.
} 


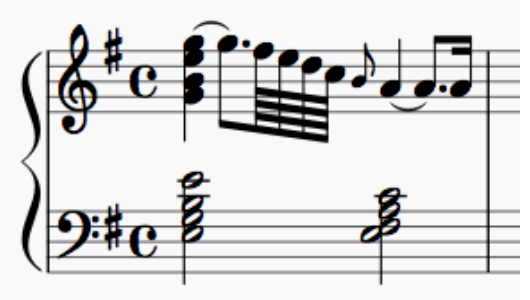

Fig. 1

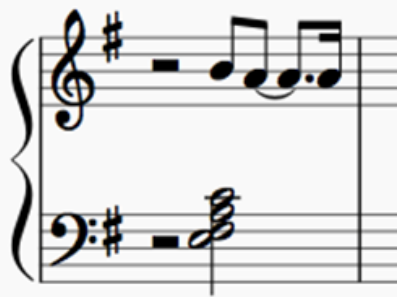

Fig. 2

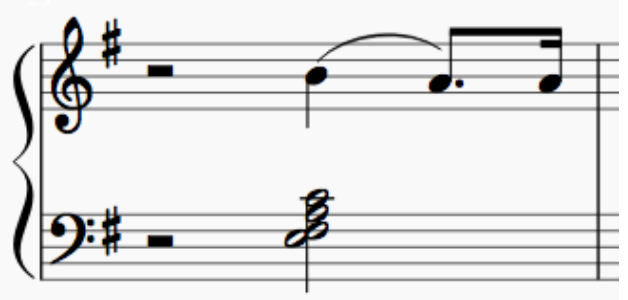

Fig. 3

\subsection{Dotted rhythm}

In the previous examples it is clear that the duration of the note as it appears in the text has been compromised. To confirm how flexible an element it was in eighteenth century music it suffices to describe another common practice of the time. C. P. E. Bach and Quantz both agreed that dotting a note was seen as a means to extend it to its maximum duration rather than count it in mathematically precise smaller values. The note after the dot would therefore sound shorter than its written value (ibid, 104). In other words a dot signified the minimal value of the dotted note while in practice it was common to play it longer, or even as a double dot. This practice applies equally to the short note that follows it or a group of short notes: in both cases they are to be played in smaller values than the written ones, and in the latter C. P. E. Bach even recommends the fastest execution possible regardless of the overall tempo of the work (Quantz 2001, 67).

Both instructions illustrated above can be applied to the first bar of the sonata. The right hand has a crotchet tied to a dotted quaver which is followed by a group of four demisemiquavers. Similarly, the last note in the right hand is a semiquaver which follows the main note $a$ with the appoggiatura already discussed. In Figure 4 the text is altered rhythmically again and shows how the first bar should sound according to the composer: 


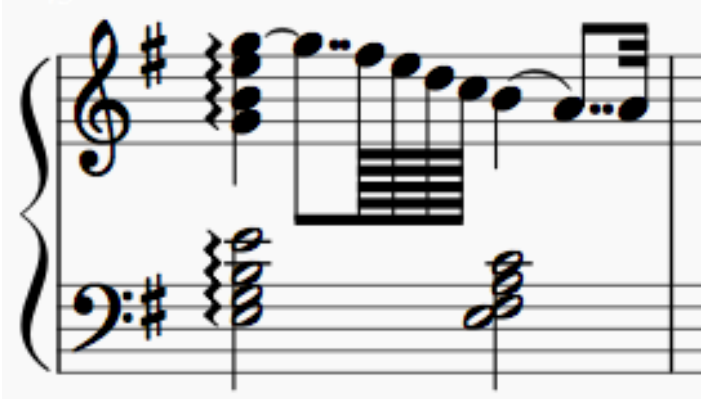

Fig. 4

Similar modifications should be made in the fourth bar of the first movement or in some ornaments in the second movement. In the first case, third beat appoggiatura $e$ decorates its main note $d$ \#. The fact that it is followed by a rest means that the main note lengthens, the appoggiatura becoming a crotchet while the rest disappears (Figure 5). The trills (tr) in the second movement, should always start on the top note according to the composer's description. Still, if the trill is preceeded by a note of the same pitch as the top triller note, in practice it is tied to the main note of the trill. This way it sounds as if the trill begins on the bottom note even if slightly later than written (Figure 6). There are many examples in the piece which should be treated in the same way. The ones presented here are not to be considered a rarity or an exception but rather as part of a performance practice and style that was so widespread and common (at least in North Germany) that writing it down seemed unnecessary. A modern performer who is unaware of the historical developments could not possibly contemplate altering the score in a similar way and would probably adopt the conventions of the later Classical style which would be inappropriate.

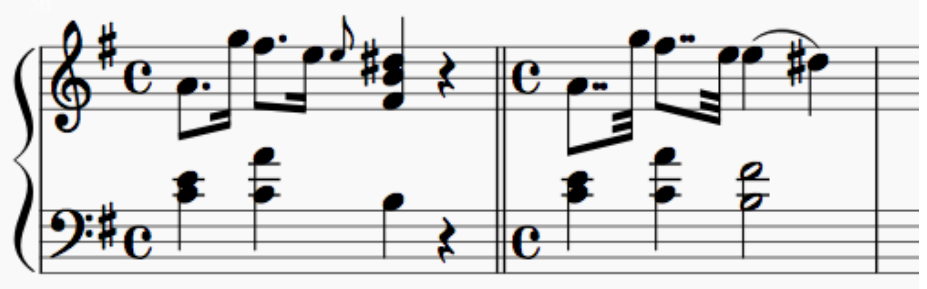

Fig. 5

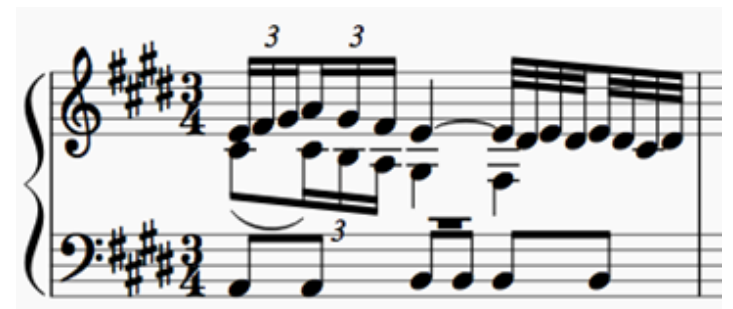

Fig. 6 


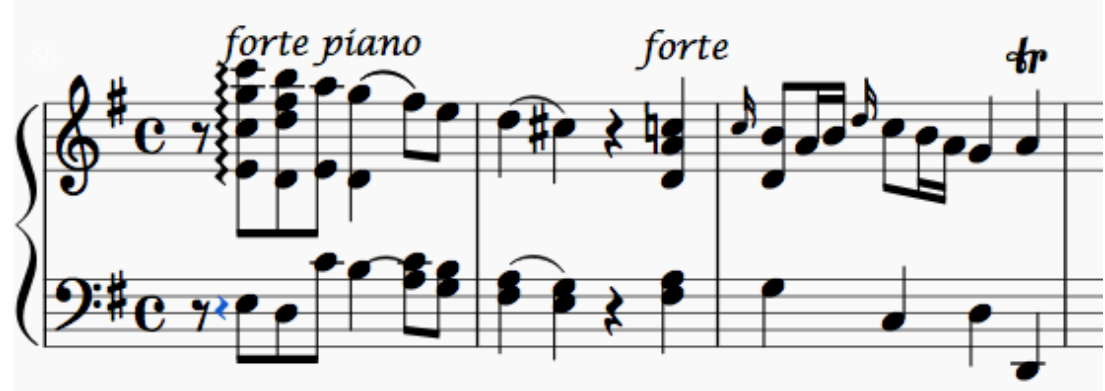

Fig. 7

\subsection{Dynamic markings}

What is to be said about the secondary layer of the musical score that might or might not be written down? The apparent frequency of dynamic markings forte and piano seem like useful intructions to a performer on a modern piano (Figure 7). From a historical practice point of view, the conclusions are more complex than performing these bars in contrasting sound volumes. The first step is to determine for which instrument the composer was writing and more specifically, which one suited this particular sonata best.

Carl Philipp had three instruments at his disposal: a harpsichord, a clavichord, and later, a fortepiano. Six Württemberg Sonatas were written around 1743 when the author was twenty nine and are considered his earlier works. The dynamic contrast marked in the score is achievable on a double manual harpsichord, by using the top keyboard (a little bit inconvenient in fast tempo) or on a clavichord. The title page gives no clues to which was the prefered instrument for the cycle, probably because the industrious, selfpublisher Carl Philipp wanted his music to be widely dissiminated among clavier players. His personal instrument of choice however was a clavichord made by Silbermann (Bach $1949,16)$. When writing for clavichord he would add dynamic changes in quick sucession just as they appear in the score. If the third sonata was written on a clavichord it makes sense to envisage Bach making many other dynamic nuances that this instrument was capable of (unlike the harpsichord) and which are not written down. The composer was apparently an inspirational performer, many collegues and contemporaries witnessing his strong expression and imagination (ibid, 15) at the keyboard which correlates to the quick changes of affect typical of Empfindsamer stil. The clavichord seems like a more suitable instrument to this particular sonata as it was able to respond to the composer's artistic demands. If this is true, it gives answers to some questions of the modern performer: the fact that dynamic markings are not in the score throughout the piece does not call for flat or terraced dynamics!

\section{CONCLUSION}

Traditional notation and its symbols were not always used in the same way or for the same purpose. This paper expresses our hope to show that not even the primary layers of a note (its height and duration) can be taken for granted in the music of this period. Even though the same symbols and signs (appoggiaturas, rests, dots etc.) were used, their meaning was different from the accepted norm of today. To read the score with proper 
understanding and create an intepretation, the performer needs to be aware of these discrepancies: it is like adopting new rules to an old game. In addition, it is also about discovering past performance practices that were left unwritten in the score. Studying historical sources will not only be an aid in learning ,how to read" the score belonging to a particular style but also to a particular composer who had created an individual style partly by using the notation to suit his own needs and ideas. However, an informed performer can only be so if in tandem with music score publishers and editors. They similarly need to make certain decisions regarding the modification of older texts where many elements of style are invisible to a modern performer. By resolving all of these issues in print, many potential interpretation dilemmas are avoided but the downside is that the performer's understanding of the style remains uninformed. It is idealistic to presume that composers' ideas and conditions could (or should) be precisely reconstructed in modern day performances even with all the knowledge acquired from available sources. It is likely that similar questions and problems would have arised in the eighteenth century too: musicians were usually proficient in one particular style belonging to the place where they worked and/or to a specific school. The period was characterised by many national tendencies (and «dialects» within each style) that did not necessarily aspire to a mutual goal, one that would later be named Viennese Classicism. It is questionable how familiar these musicians were with any music outside their expertise. How else to describe the reason behind C. P. E. Bach's effort spreading over four hundred written pages?

\section{REFERENCES}

Bach, C. P. E. (1949). Essay on the True Art of Playing Keyboard Instruments (trans. and ed. by William J. Mitchell). New York/London: W. W. Norton \& Company.

Bach, C. P. E., Wurttemberg Sonata No.3 [partitur facsimile], http://petrucci.mus.auth.gr/imglnks/usimg/ b/b7/IMSLP77701-PMLP09327-C_P_E_Bach__Württemberg_Sonatas.pdf, acc. 8. 1. 2012 at 12:40 PM

Bach, C. P. E., Wurttemberg Sonata No.3 [partitur], Nagels Musik Verlag, Leipzig, ca. 1930. http://imslp.info/ files/imglnks/usimg/f/f2/IMSLP03752-CPEBachWürttembergSonatas.pdf, acc. 8. 1. 2012 at 1:10 PM

Quantz, J. J. (2001). On Playing the Flute (trans. and ed. by Edward R. Reilly). London: Faber and Faber.

Mozart, W. A. (2015). The Mozart Violin Concerti: A Facsimile Edition of the Autographs (ed. by Gabriel Banat). Cambridge: Courier Dover Publications,

https://books.google.rs/books?id=hyyBwAAQBAJ\&pg=PR14\&dq=the+mozart+violin+concerto+a+facsimile+ed ition\&hl=en\&sa=X\&ved=0CB8Q6AEwAGoVChMImqyvuZ2HxgIVSVksCh2EFgAc\#v=onepage \&q=the $\% 20 \mathrm{~m}$ ozart\%20violin\%20concerto\%20a\%20facsimile\%20edition\&f=false, acc. 10. 5. 2015 at 10:25 AM

Popović-Mlađenović, T. (1996). Muzičko pismo. Beograd: Clio.

\section{STUDIJA SLUČAJA: ČITANJE VIRTEMBERŠKE SONATE BR. 3 KARLA FILIPA EMANUELA BAHA}

U radu ćemo pokušati da ispitamo pouzdanost primarnih elemenata tona - visinu i trajanje koji deluju fiksirani u partituri. Analizirom kompozitorovog muzičkog jezika, istorijske izvođačke prakse i načina korišćenja notnog pisma, takođe ćemo pokušati da rasvetlimo onaj sloj partiture koji je ostao nezapisan. Na taj način će se pojasniti u kojoj meri su zapravo odluke koje izvođač donosi spontane i proizvoljne.

Ključne reči: istorijska izvođačka praksa, notno pismo, ritam, ukrasi, osećajni stil, K. F. E. Bah 